\title{
Solution-Focused School Leadership Scale: A Validity and Reliability Study
}

\author{
Şenol Sezer \\ Ordu University, Ordu, Turkey
}

\begin{abstract}
The aim of this study was to develop a new brief scale to determine school administrators' solution-focused school leadership features. Additionally, it was aimed to explore the psychometric properties including factor structure, reliability and validity analysis of the Solution-Focused School Leadership Scale (SFSLS). The data were collected from 192 teachers. The results of the study suggested two-factor subscales for SFSLS. Factor structure of SFSLS was examined by means of exploratory and confirmatory factor analysis. In general, the SFSLS demonstrated adequate model fit, showed strong internal consistency and correlated with the SFSLS subscales. In total, the findings support that the SFSLS is a valid and reliable measure to determine school administrators' solution-focused school leadership features. This scale can be considered crucial in determination of school administrators' solution-focused school leadership features so that solution-focused school management strategies can be developed to handle various problems of schools.
\end{abstract}

Keywords: solution-focused, school leadership, scale development, reliability, validity

\section{Introduction}

The solution-focused approach was developed by de Shazer and Berg in the first half of the 1980s at the Brief Family Therapy Centre (BFTC) in Millwaukee. This approach is a powerful, practical and proven approach to ensure positive change with people, teams and organisations. The radical simplicity of this approach is to take the direct route forwards, and simply head straight for the solution by sidestepping the often fruitless search for the causes of problems. Solution-focused thinking is not to say "There is a solution for every problem, all we have to do is look and we'll find it". In contrast, solution-focused thinking process is characterized by a style of thinking that eschews excessive focus on problems and their causes. This approach focuses on identifying goals and unnoticed resources of organisation, and finding multiple pathways to achieve those goals. Consequently beginning from the early experiments in the mid-1990s, the solution-focused approach has become increasingly influential.

This concept, also originally known as brief counselling and now has widely entered in society and currently spreads through the areas such as consulting and management (Visser, 2013). Over the past 25 years, the solution-focused approaches have been the many applications found in management area and organisational change (Gingerich \& Peterson, 2013). The focus on solutions (not problems), strengths (not weakness), and what's going well (rather than what's going wrong) leads to a positive and pragmatic way of

Şenol Sezer (Corresponding Author), Ph.D., Assist. Prof., Faculty of Education, Educational Administration Department, Ordu University. Email: senolsezer.28@gmail.com, Gsm: +90530 5183552. 
making progress (Jackson \& McKergow, 2007). Solution-focused approach is based on exploring and amplifying strengths and successes rather than focusing on problems (de Jong \& Berg, 2002). Emphasising on deficits usually leads to an extensive time-consuming for exploration the etiology, histories and causes of the problems (Sklare, 2005).

The solutions-focus term refers to the process by which the stakeholders co-construct a "solution"- - that is finds a way forward - in collaboration with the leader. By doing so it enlarges the range of potential actions open to the stakeholders (Cavanagh \& Grant, 2010; Grant, 2001). If these opportunities are used for learning the best opportunities for personal performance improvement usually happen during daily work situations. Solutions focused scaling questions help to make the most of these learning opportunities in less than 10 minutes. The questions are simple to ask, easy to slip into any professional conversation and they have been proven to work. A solution-focused leader can use them to facilitate performance and learning for others (Berg \& Szabo, 2005). It can be said that the solution-focused approach is a strengths-based approach which emphasizes people's resources and resilience and how these can be used in the pursuit of purposeful, positive change. Moreover, individuals perform the change choose the behaviours based on their previous successes (Grant, Cavanagh, Kleitman, Spence, Lakota, \& Yu, 2012; Stams, Dekovic, Buist, \& de Vries, 2006).

Leadership takes place in social systems and in social settings. Obviously leadership is a social process, in as much as leaders function in social systems and in social settings. Interactions among people comprise social processes, such as influence, acceptance and rejection, trust, conflict, competition, and cooperation, among others. Thus, as leaders interact with individuals and with social systems, they are engaging in social processes (English, 2006, p. 579). Solution-focused leadership as a leadership style not only encourages good solutions and high employee engagement, but is also a promise for an organisation's success in a demanding fast-changing dynamic world (Godat, 2013). The focus of solution-focused leadership is on the difference between problem and solution, and this difference conceivable keeps leaders and stakeholders equally busy. One of the most important core elements of the solution-focused leadership is the focusing on "what is different when it is better". "Focusing on positive differences" is at the centre of this approach (Lueger, 2006). The solution-focused leadership is a conscious and deliberate to changing the way you view situations and circumstances. It is a simple practical approach to solve the problems (Grant, 2003). Just because it is so practical and simple it is tempting to dismiss this type of thinking as vague or too soft but many organisations are beginning to realize that it is just this type of soft skills that are crucial to their success. In fact, the soft skills are often hardest to utilize (Green \& Grant, 2003). Solution-focused leadership techniques include complimenting as well as collaboration and teamwork as the positive leadership qualities (Froeschle \& Nix, 2009). Appreciation is an important part of solution-focused leadership. The solution-focused leadership approach gives us a wonderful and effective tool to appreciate and develop existing resources in others, and primarily to help them to realise their own resources (Duclos, 2006). According to Röhrig (2006), in solution-focused approach appreciation is more effective feedback as well as a very powerful way to start the resources in stakeholders.

The solution-focused approach says that when faced with a difficult situation you need to clarify goals, decide what you want to change, see the problem as something you have (not are), focus on times when you have coped, chart your progress towards the solution, clarify the central goal or issue, look at your strengths and successes (Green \& Grant, 2003). Solution-focused leaders, furthermore, foster solution-focused 
interactions in between stakeholders. The interactions focus on platform building, future perfect, discovering what works, affirming, small next steps, and experiments, either or all of them or a selected subset (Godat, 2013). A solution-focused leader (1) focuses on the potential of stakeholders; (2) clarifies the hopes, goals, and aspirations; (3) considers how might be tapped into the resources even more in order to achieve these goals by remembering small steps make a big difference; (4) challenges any negative self-talk; (5) focuses on the preferred future as a leader and considers how can be done more of what works; and (6) clarifies immediate action plans and next steps (O'Connell, Palmer, \& Williams, 2012). In many ways, this is not a surprising development; the pragmatic and effective nature of the approach matches the desire for efficient ways to make progress found in most organisations (Cavanagh \& Grant, 2010; de Shazer, 1988; O'Connell, 1998). Although more and more solution-oriented people work in organisations, solution-focused approach is still widely seen as a therapy, coaching, training or facilitating approach, but not yet as a leadership style (Grant, Franklin, \& Langford, 2002).

\section{Solution-Focused School Leadership (SFSL)}

Schools can be places of solutions, strengths, and successes. In a rapidly changing world, school leaders must be able to identify and solve problems inside the school as well as in the school's environment (Bridges \& Hallinger, 1997). In enacting or carrying out solution to the problem, the school leaders not only apply the analytical thinking skills traditionally valued in schools, but also develop skills in solution-focused leadership (Hallinger \& Bridges, 1997). There are numerous practical ways for solution-focused leadership to harness the solutions that are already happening in the schools. This strengths-based approach is a major theme throughout the solution-building school and solution-focused educational leadership which offers all administrators specific skills for fostering strengths in teachers (Iveson, George, \& Ratner, 2012; Roeden, Maaskant, Bannink, \& Curfs, 2011). For example, identifying the teacher's strengths helps to build confidence in a teacher that a solution is possible and empowers the teacher to continue building on his or her strengths. This helps to create positive changes for the teachers quickly and shifts the focus away from the negatives (Kelly, Kim, \& Franklin, 2008).

Solution-focused conversation techniques are quite effective for solution-focused school leadership. Especially appropriate praises and resourceful questioning can be usefully integrated school leaders' everyday conversations (Cavanagh, 2008). A school leader can better assist to the teachers by encouraging them about to use own resources, empowering and helping them to believe in a future success. In other words, a school leader can better motivate the teachers by appreciating, because the appreciation builds a bridge from social level to the self-esteem (Jackson \& McKergow, 2007). When teachers' self-esteem satisfied they begin to feel they are useful and they have some effects on their environment. If school leaders praise their colleagues' strengths appropriately it is more effective from to criticise theirs weaknesses (Grant \& Spence, 2010; Kashdan \& Rottenberg, 2010; Peterson, 2006). School leaders can extend their praise competences through some practises on solution-focused questions. For example, when they show an honest interest in the answer they can ask more frequently about "How did you do it", "Which suggestions come to you mind" or "How could we do that even better" (Grant, Curtayne, \& Burton, 2009). Key assumptions of solution-focused school leadership can be mentioned, namely (1) If it isn't broke, don't fix it, if it works, do more of it, if it doesn't work, do something different; (2) Everybody is unique, resourceful, and capable of changing; (3) Individuals are experts on their own lives; (4) The individual's own goal drives the activities; (5) Everybody is invested in solutions they 
generate; (6) No problem is constant; and (7) Big problems do not always require big solutions (Murphy, 1997).

Several instruments have been developed on solution-focused inventory namely, The Solution Building Inventory (Smock, McCollum, \& Stevenson, 2010), The Solution-Focused Inventory (Grant et al., 2012). The first scale attempted to comprehensively measure all aspects of "solution-building processes" built by client in brief solution-focused therapy (Smock, McCollum, \& Stevenson, 2010). The second scale attempted to measure all aspects of "solution-focused thinking" so will be useful in cognitive-behavioural therapy and positive psychology interventions (Grant et al., 2012). Şanal-Karahan and Hamarta (2015) had adapted to Turkish and examined the validity and reliability of the Solution-Focused Inventory.

\section{The SFSLS: Theoretical Factor Structure}

In developing process of the SFSLS, solution-focused literature was reviewed broadly. In order to develop of solution-focused school leadership scale and more deeply explore their utility in school administration, school development and positive change, a new theoretically grounded and empirically validated measure that can assess processes central to solution-focused school leadership is needed. A brief, reliable and valid measure of solution-focused school leadership would have potential to contribute to the field, both in terms of assessing change in the school administration targeted by solution-oriented interventions, and more broadly in terms of generating insight into the school development processes central to purposeful positive change. For such a measure to be useful to both practitioners and researchers, it needs to be theoretically grounded, simple to administer and easy to score. The aim of this study was to develop such a measure. The development of solution-focused school leadership scale was conducted in four stages.

\section{Procedure}

(1) Composing item pool: Firstly, the 24 items related to solution-focused school leadership were determined based on literature.

(2) Applying expert opinion: Secondly, the expert opinion was applied in order to provide fitting of each items for solution-focused school leadership scale. Finally, 24 items were formatted with 8-point Likert scales ranging from 1 ("Strongly disagree") to 8 ("I strongly agree").

(3) Rewriting of items: Thirdly, some items were changed and rewritten according to the four experts' views studying in solution-focused leadership and solution-focused brief counselling field.

(4) Item analysis, exploratory and confirmatory factor analysis: Fourthly, the item analysis, exploratory factor analysis and confirmatory factor analysis processes were conducted to provide validity and reliability of solution-focused school leadership scale.

\section{Results}

\section{Solution-Focused School Leadership Scale (Study I)}

Item analysis. Item analysis is an investigating and analysing process to determine participants' responses to each item and also what extend each item is sufficient to measure the participants' attitudes (Everitt, 2006). At this stage, it is intended to examine the psychometric properties of the Solution-Focused School Leadership Scale related to the construct validity. Firstly, the Z-test analysis was performed on the total scores given by the study group to the each items in the solution-focused school leadership scale. According to the Z-test results, it 
was determined that all of data ranged between -3 to +3 . Then the Cronbach analysis was applied to all items and evaluated their effects on whole scale.

Exploratory Factor Analysis (EFA). In factor analysis process, Kaiser-Meyer-Olkin (KMO) and Barlett Sphericity test were applied to analyse in order to determine whether the items were suitable for factor analysis (Field, 2005). The KMO value was found as 0.90 and Barlett's Test of Sphericity was found as significant $\left(x_{(55)}^{2}=1050.79, p<0.001\right)$. Both these results indicated that the number of participants was big enough and the data were appropriate to the factor analysis (Leech, Barrett, \& Morgan, 2005). During the EFA, a factor loading value of 0.30 was accepted as a criterion for the retention of the items (Field, 2005; Hair, Anderson, Tatham, \& Black, 1998; Nunnally \& Bernstein, 1994). Based on the criterion, 13 items were eliminated due to the insufficient correlation between the sum score of the 24 items. Consequently after the elimination process the two factor scale accounting $59.07 \%$ of total variance was developed. The scale consisted of 11 items and item-total correlations ranged from 0.52 to 0.85 . Based on the content of factors, Factor One was labelled as "exemplifying", and Factor Two as "encouragement". The results can be seen in Table 1.

Table 1

Factor Loadings, Means, and Standard Deviations $(n=192)$

\begin{tabular}{|c|c|c|c|c|c|}
\hline \multirow{2}{*}{ Item } & \multirow{2}{*}{ The principal; } & \multicolumn{2}{|c|}{ Factor loadings } & \multirow[b]{2}{*}{$\bar{X}$} & \multirow[b]{2}{*}{$S S$} \\
\hline & & Factor 1 & Factor 2 & & \\
\hline M23 & Considers solution suggestions of the staff & 0.845 & & 7.15 & 1.32 \\
\hline M19 & Supports staff in problem solving process & 0.818 & & 6.68 & 1.80 \\
\hline M24 & Appreciates problem solving skills of the staff & 0.802 & & 6.72 & 1.35 \\
\hline M21 & Thanks to those who contributed to the solution & 0.786 & & 7.22 & 1.50 \\
\hline M22 & Regards as valuable even least actions for solution & 0.781 & & 7.40 & 1.13 \\
\hline M20 & Gives confidence to staff & 0.741 & & 7.31 & 1.15 \\
\hline M17 & Provides a working environment based on collaboration & 0.732 & & 7.42 & 0.98 \\
\hline M14 & Maintains the applications engendering positive results & & 0.689 & 7.51 & 1.00 \\
\hline M1 & Expresses as "There is a solution for each problem" & & 0.686 & 7.26 & 1.19 \\
\hline M3 & Avoids from using negative discourses & & 0.578 & 7.35 & 1.14 \\
\hline \multirow[t]{3}{*}{ M12 } & Prepares urgent action plan for problem solving & & 0.525 & 7.43 & 1.16 \\
\hline & Eigen values: & 5.35 & 1.14 & & \\
\hline & $59.07 \%$ & 40.98 & 18.08 & & \\
\hline
\end{tabular}

Note. $p<0.01, \bar{X}=$ Mean, $S S=$ Standard Deviation.

Confirmatory Factor Analysis (CFA). The two factor model was tested using confirmatory factor analysis by means of LISREL 8.51 in order to further examine the factorial structure. In order to account for the model, the data was established with the fit indices. In a general manner, fit indices values enable researchers to accept or refuse the model. The results were reported for several fit indices as follow: $x^{2} / d f$, RMSEA (Root Mean Square Error of Approximation), CFI (Comparative Fit Indices), IFI (Incremental Fit Index), GFI (Goodness of Fit Index), AGFI (Adjusted Goodness of Fit Index), NFI (Normed Fit Index), NNFI (Non-Normed Fit Index), RFI (Relative Fit Index), and SRMR (Standardized Root Mean Square Residual). General agreements are $x^{2} / d f$ values of 2 or lower and CFI, IFI, GFI, AGFI, NFI, NNFI, RFI values of 0.90 or greater indicate satisfactory fit; RMSEA and SRMR values of 0.05 or lower show excellent fit (Çokluk, 
Sekercioğlu, \& Büyüköztürk, 2012; Kline, 2005). After the required and suggested modification indices (19-20) which were similar in theoretical basis were applied to improve the model, results of the first order confirmatory factor analysis indicated that the model was convenient to the data: $x^{2}{ }_{(192)}=70.55, p<0.001 ; x^{2} / d f$ $=1.68, \mathrm{RMSEA}=0.06 ; \mathrm{CFI}=0.97 ; \mathrm{IFI}=0.97 ; \mathrm{GFI}=0.94 ; \mathrm{AGFI}=0.90 ; \mathrm{NFI}=0.93 ; \mathrm{NNFI}=0.96, \mathrm{SRMR}=$ $0.04, \mathrm{RFI}=0.91$. Factor loading of 11 items were presented in Figure 1.

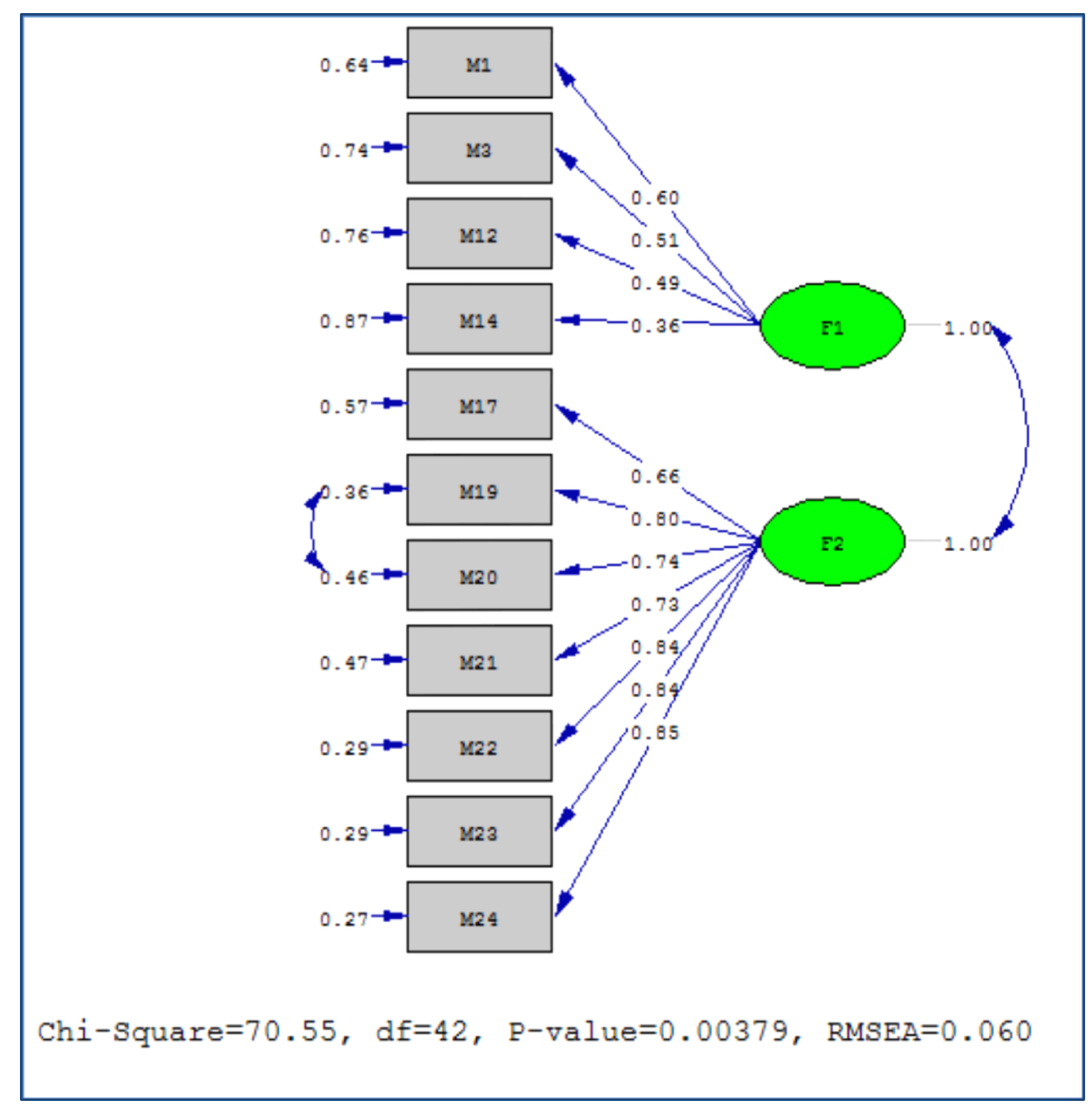

Figure 1. Factor loadings for the SFSLS.

\section{Solution-Focused School Leadership Scale (Study II)}

Test-retest reliability. After the first exploratory and confirmatory factor analysis of Solution-Focused School Leadership Scale with two factors and 11 items it was applied to 191 teachers. After the second implementation of SFSLS, the results of the second order confirmatory factor analysis indicated that the model was convenient to the data: $x_{(191)}^{2}=63.67, p<0.001 ; x^{2} / d f=1.48, \mathrm{RMSEA}=0.05 ; \mathrm{CFI}=0.98$; IFI $=0.98$; GFI $=0.94 ; \mathrm{AGFI}=0.91 ; \mathrm{NFI}=0.94 ; \mathrm{NNFI}=0.97, \mathrm{SRMR}=0.04, \mathrm{RFI}=0.92$. Factor loading of 11 items were presented in Figure 2. 


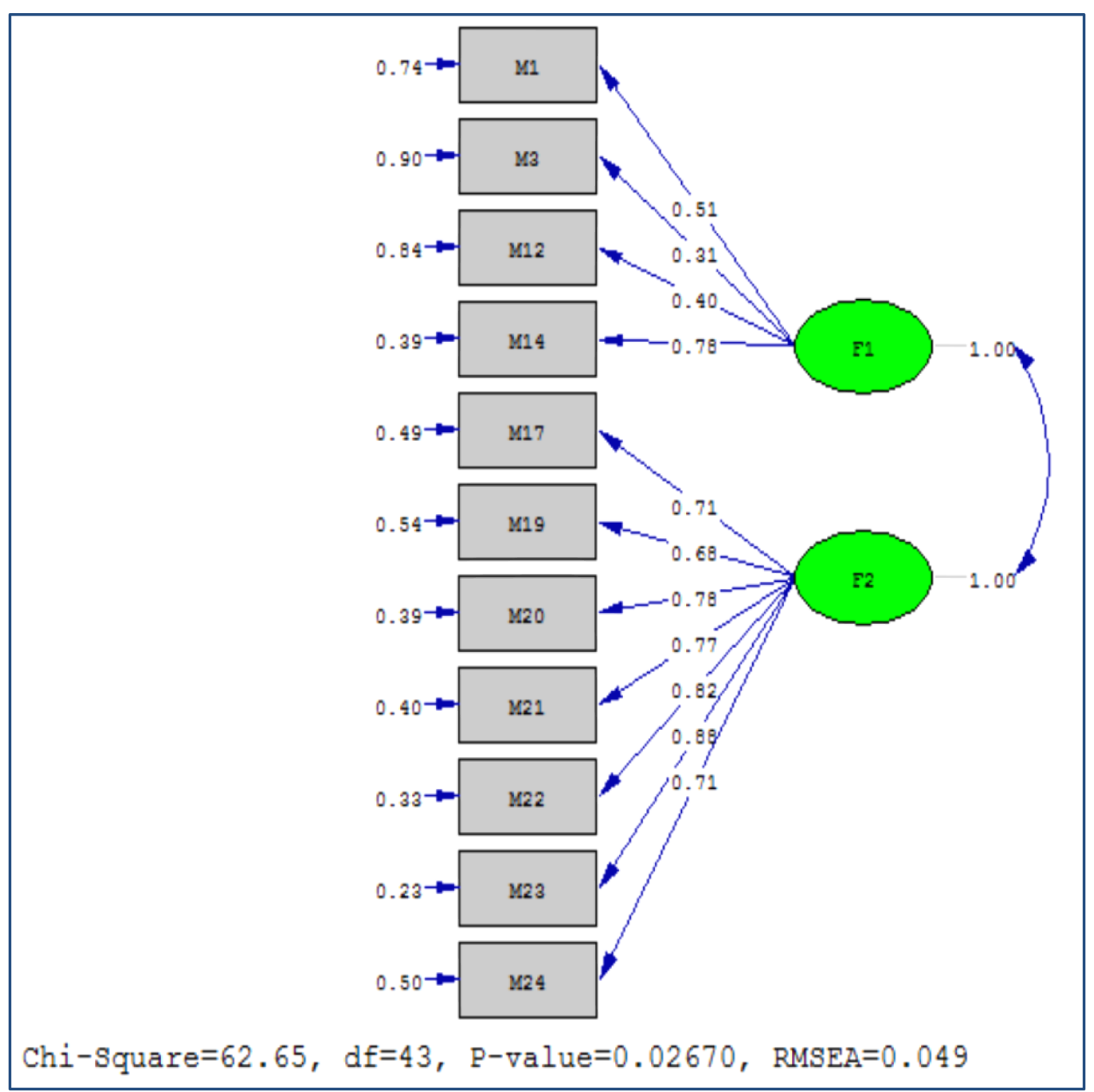

Figure 2. Factor loadings for the SFSLS.

\section{Conclusion}

The purpose of this study was to develop and investigate of solution-focused school leadership scale designed to determine school administrators' solution-focused leadership features. Overall, the SFSLS appears to be a developmentally appropriate measure with sufficient preliminary evidence for the reliability and validity of its scores. In this study, factor structure of the SFSLS was examined by means of exploratory and confirmatory factor analysis, respectively. The exploratory factor analysis performed with 11 items retained from initial pool showed that there were two subscales accounted for $59.07 \%$ of total variance. Given the minimum total variance criteria as 0.30 in social sciences, it can be asserted that this scale provides construct validity (Field, 2005). These two factors structure was confirmed by CFA. CFA results demonstrated that the factorial model of the SFSLS was at an acceptable degree of goodness of fitting. As reliability coefficient of 0.70 was stipulated as an acceptable criterion for the internal consistency, and the SFSLS exhibited acceptable reliability coefficients and satisfactory test-retest reliability coefficients (Creswell, 2002). After item analysis, it was determined that the corrected item total correlations supported to the criteria as the cut-off item total point. 
Therefore, the scale items are useful to determine and assessment of school administrators' solution-focused school leadership features. According to results of validity and reliability analysis, it can be concluded that the SFSLS presented adequate model, demonstrated strong internal consistency and correlated with the SFSL subscales as expected in every case. The SFSLS is an instrument aimed to assess school administrators' solution-focused school leadership features within two subscales entitled as "exemplifying" and "encouragement". This scale has 11 items, formatted with 8-point Likert scales ranging from 1 ("I strongly disagree") to 8 ("I strongly agree"), reflecting university students' problem areas. There are no reverse scored items. In present study, there are some potential limitations. A few recommendations were asserted by researchers based on these limitations. First of all, the SFSLS is still need of further psychometric validation. This study was conducted in a city located in North side of Black Sea Region in Turkey. In addition, the teachers were working in city centre. Hence, solution-focused leadership perception could be differentiated among the teachers working in rural and urban schools. So the factor structure of SFSLS should be carried out with the teachers working in school in rural regions. Further studies should be conducted to support the usefulness of the scale as well as test-retest reliability. Another limitation of this study is that the findings from this research only based on quantitative research approach. So I should recommend that these results should be supported by picking qualitative data. In further studies, SFSLS should be applied to determine schools administrators' solution-focused school leadership features comprehensively. Consequently, the data support that SFSLS is a valid and reliable scale to determine the solution-focused leadership features of the school administrators.

\section{References}

Berg, I. K., \& Szabo, P. (2005). Brief coaching for lasting solutions. NY: Norton.

Bridges, E. M., \& Hallinger, P. (1997). Using problem-based learning to prepare educational leaders. Peabody Journal of Education, 72(2), 131-146.

Cavanagh, M. (2008). Creating flourishing leadership through developmental coaching. First Australian Positive Psychology and Well-Being Conference, 5-6 April, 2008, Sydney, Australia.

Cavanagh, M., \& Grant, A. M. (2010). The solution-focused coaching approach to coaching. In E. Cox, T. Bachkirova, \& D. Clutterbuck (Eds.). Sage handbook of coaching (pp. 34-47). London: Sage Publications.

Creswell, J. W. (2002). Educational research: Planning, conducting, and evaluating quantitative and qualitative research. New Jersey: Merrill Prentice Hall.

Çokluk, Ö., Şekercioğlu, G., \& Büyüköztürk, Ş. (2012). Sosyal bilimler için çok değiskenli SPSS ve LISREL uygulamaları. Ankara: PegemA Yayıncilik.

de Jong, P., \& Berg, I. K. (2002). Interviewing for solutions. Pacific Grove, CA: Wadsworth.

de Shazer, S. (1988). Clues: Investigating solutions in brief therapy. New York: Norton \& Co.

Duclos, M. (2006). Solution-focused leadership through appreciation. In G. Lueger, \& H. P. Korn (Eds.), Solution-focused management (pp. 123-133). München: Rainer Hampp Verlag.

English, F. W. (Editor). (2006). Encyclopaedia of educational leadership and administration. London: Sage Publications.

Everitt, B. S. (2006). The Cambridge dictionary of statistics (3rd ed.). Cambridge: Cambridge University Press.

Field, A. (2005). Discovering Statistics Using SPSS (2nd ed.). London: Sage Publications.

Froeschle, J., \& Nix, S. (2009). A solution-focused leadership model: Examining perceptions of effective counsellor leadership. Journal of School Counselling, 7(5), 1-21.

Gingerich, W. J., \& Peterson, L. (2013). Effectiveness of solution-focused brief therapy: A systematic qualitative review of controlled outcome studies. Research on Social Work Practice, 23, 266-283. DOI:10.1177/1049731512470859

Godat, D. (2013). Solution focused leadership-the other side of the elephant: Four distinctions between SFL and SF coaching. InterAction, 5(2), 20-34.

Grant, A. M. (2001). Rethinking psychological mindedness: Meta-cognition, self-reflection and insight. Behaviour Change, 18(1), 8-17. DOI:10.1375/bech.18.1.8 
Grant, A. M. (2003). The impact of life coaching on goal attainment, metacognition and mental health. Social Behavior and Personality, 31(3), 253-264.

Grant, A. M., \& Spence, G. B. (2010). Using coaching and positive psychology to promote a flourishing workforce: A model of goal-striving and mental health. In P. A. Linley, S. Harrington, \& N. Page (Eds.), Oxford handbook of positive psychology and work (pp. 175-188). Oxford: Oxford University Press.

Grant, A. M., Franklin, J., \& Langford, P. (2002). The self- reflection and insight scale: A new measure of private self-consciousness. Social Behavior and Personality, 30(8), 821-836. DOI:10.2224/sbp.2002.30.8.821

Grant, A. M., Cavanagh, M. J., Kleitman, S., Spence, G., Lakota, M., \& Yu, N. (2012). Development and validation of the solution-focused inventory. The Journal of Positive Psychology, 7(4), 334-348.

Grant, A. M., Curtayne, L., \& Burton, G. (2009). Executive coaching enhances goal attainment, resilience and work-place well-being: A randomized controlled study. Journal of Positive Psychology, 4(5), 396-407. DOI:10.1080/17439760902992456

Green, J., \& Grant, A. M. (2003). Solution-focused coaching. London: Pearson Education Limited.

Hair, J. F., Anderson, R. E., Tahtam, R. L., \& Black, W. C. (1998). Multivariate data analysis (5th ed.). New Jersey, NJ: Printice-Hall.

Hallinger, P., \& Bridges, E. M. (1997). Problem-based leadership development: Preparing educational leaders for changing times. Journal of School Leadership, 7(6), 592-608.

Iveson, C., George, E., \& Ratner, H. (2012). Brief coaching: A solution-focused approach. New York: Routledge.

Jackson, P. Z., \& McKergow, M. (2007). The solutions focus. London: Nicholas Brealey.

Kashdan, T. B., \& Rottenberg, J. (2010). Psychological flexibility as a fundamental aspect of health. Clinical Psychology Review, 30, 885-878.

Kelly, M. S., Kim, J. S., \& Franklin, C. (2008). Solution-focused brief therapy in schools: A 360-degree view of research and practice. New York: Oxford University Press.

Kline, R. B. (2005). Principles and practice of structural equation modelling. New York, NY: Guilford Press.

Leech, N. L., Barrett, K. C., \& Morgan, G. A. (2005). SPSS for intermediate statistics; use and interpretation (2nd ed.). Mahwah, NJ: Lawrence Erlbaum Associates.

Lueger, G. (2006). Solution-focused management: Toward a theory positive differences. In G. Lueger, \& H. P. Korn (Eds.), Solution-focused management (pp. 1-13). München: Rainer Hampp Verlag.

Murphy, J. J. (1997). Solution-focused counselling in middle and high schools. Alexandria: American Counselling Association.

Nunnally, J., \& Bernstein, I. (1994). Psychometric theory. New York: McGraw-Hill.

O'Connell, B. (1998). Solution-focused therapy. London: Sage Publications.

O'Connell, B., Palmer, S., \& Williams, H. (2012). Solution focused coaching in practice. London: Routledge.

Peterson, C. (2006). A primer in positive psychology. New York: Oxford University Press.

Roeden, J. M., Maaskant, M. A., Bannink, F. P., \& Curfs, L. M. (2011). Solution-focused brief therapy with people with mild intellectual disabilities: A case series. Journal of Policy and Practice in Intellectual Disabilities, 8, 247-255.

Röhrig, P. (2006). Advanced training for basic leadership skills. In G. Lueger, \& H. P. Korn (Eds.), Solution-focused management (pp. 147-155). München: Rainer Hampp Verlag.

Sklare, G. B. (2005). Brief counselling that works: A solution-focused approach for school counsellors and administrators. California: Corwin Press.

Smock, S. A., McCollum, E. E., \& Stevenson, M. L. (2010). The development of the solution building inventory. Journal of Marital and Family Therapy, 36, 499-510.

Stams, G. J., Dekovic, M., Buist, K., \& de Vries, L. (2006). Efficacy of solution-focused brief therapy: A meta-analysis. Gedrags Therapie, 39, 81-94.

Şanal-Karahan, F., \& Hamarta, E. (2015). Çözüm odaklı envanter: Güvenirlik ve geçerlik çalışması. İlköğretim Online, 14(2), 757-769. http://dx.doi.org/10.17051/io.2015.15313

Visser, C. F. (2013). The origin of the solution-focused approach. International Journal of Solution-Focused Practices, 1(1), 10-17. DOI:10.14335/ijsfp.v1i1.10 